\title{
ANALYZING TRIALS THROUGH ONLINE MEDIA DURING THE COVID-19 PANDEMIC IN INDONESIA
}

\author{
Angga Putra Pratama ${ }^{*}$, Dewa Gede Pradnya Yustiawan ${ }^{2}$ \\ ${ }^{1}$ Faculty of Law, Universitas Udayana \\ 2 Faculty of Law, Universitas Udayana \\ E-mail: ${ }^{1)}$ anggaputraprat39@gmail.com, ${ }^{2)}$ pradnya_yustiawan@unud.ac.id
}

\begin{abstract}
The Corona Virus (Covid-19) pandemic is a challenge for humans to transform life activities, so that people have to adapt to changes in human activities, along with the addition of positive cases of the Covid-19 corona virus, the government enforces the Work from Home (WFH) policy. Likewise, the judicial apparatus must carry out its obligations to carry out trials, with the existence of online court media being an alternative in conducting virtual trials/teleconferences, this is a new breakthrough in conducting trials. So that people get justice and the right to get a legal process
\end{abstract}

Keywords: the judge, online media, Corona Virus (covid-19)

\section{INTRODUCTION}

The Indonesian government has issued and stipulated various regulations, especially regarding the implementation of face-to-face trials which apparently cannot be implemented and it is recommended to be replaced using a remote trial process or also called a virtual trial or online. This is carried out in an effort to decide the spread of the Covid-19 virus, namely by limiting direct or face-to-face interactions. WHO also advises the public not to carry out activities that cause crowding. In the legal field itself, the law enforcement process is hampered due to the spread of Covid-19, which is still very high in transmission, so that the law enforcement process in court activities is disrupted by trial activities. then a solution is needed to overcome this problem. To reduce crowding activities, the government issued a regulation regarding the conduct of trials by the Supreme Court to issue decisions related to the implementation of electronic trials on the basis of Supreme Court Regulation Number 01 of 2019 concerning procedures for conducting trials through electronic media, so that the trial process is not hampered and the trial continues even though the trial process continues. In the midst of a pandemic, the trial system was changed to an online or electronic trial via teleconference (Hanafi et al., 2021).

The decision of government agencies to conduct trials via electronic means based on the agreement of a Memorandum of Understanding (MoU) between the Supreme Court, the Attorney General's Office of the Republic of Indonesia and the Ministry of Law and Human Rights in this case the Directorate General of Corrections regarding the trial mechanism through online media. The $\mathrm{MoU}$ in Indonesian is translated into various terms, including "nota kesepakatan", "nota kesepahaman", "perjanjian kerja sama", or "perjanjian pendahuluan" (Matondang, nd). The purpose of making a Memorandum of Understanding is to establish a legal relationship, as a letter made by one of the parties whose contents contain the will, the letter is addressed to the other party, and based on the letter the other party is expected to make a similar letter of intent to show its intention (Mandasari, 2013). Furthermore, the contents of the MoU regarding approval related to the trial mechanism during an uncertain outbreak, so that the agreement is valid until the spread of the Covid19 outbreak is controlled in Indonesia. 


\section{POLICY, LAW, NOTARY AND REGULATORY ISSUES (POLRI) VOLUME 1 ISSUE 1 (2022)}

The MoU stipulates that the agreement on the mechanism for the trial of criminal cases through electronic/online media. Moreover, the Attorney General's order to minimize the spread and transmission of Covid 19, so that the trial is not hampered, therefore the criminal cases are tried virtually, the instruction is contained in the Attorney General's Circular regarding efforts to fulfill his obligations as the Implementation of the Duties, Functions and Authorities of the Prosecutor's Office in the midst of the Covid 19 pandemic. Based on this circular, starting from March 30 to July 6, 2020, 176,912 electronic trials have been conducted electronically (Yahya, 2020).

Electronic trial through teleconference means is a transformation of the implementation of the trial in an emergency condition, in line with the health protocol policies issued by the government regarding social distancing and physical distancing, to inhibit the growth of Covid-19 cases in court, as well as in the detention cell, and also anticipating contagion in the Correctional Institution.

As a follow-up to the MoU, the Supreme Court (MA) has issued a regulation in the form of PERMA Number 4 of 2020. This regulation is a form of response from the institution in an effort to maximize the implementation of law in Indonesia, so that it becomes the basis for conducting trials and becomes the basis as a legal shield in implementing electronic in general court, military, and criminal justice institutions (jinayah).

On the other hand, there are people who still do not understand how to operate electronic technology, and the lack of the internet network signal in remote areas, even though there is an agreement regarding the use of video conferencing in conducting trials in certain situations. The most important thing is to examine witnesses, but the readiness of electronic devices in each institution, the presence of related parties (witnesses) and the presence of defendants are not evenly distributed and adequate (Hamidah, nd).

The implementation of this electronic trial has the potential to cause fraud, so that it interferes with the principle of fair trial, if the infrastructure to support electronic justice is not in accordance with operational standards and also has the potential to reduce the validity of the evidentiary process. In addition, judges, prosecutors, defendants, legal counsel and witnesses are not in the same room (Akbar \& Sabri, 2021). The potential for pressure from various parties from the trial process or evidence will be possible.

However, Article 154 of the Criminal Procedure Code states that the defendant must be present at the trial and should not be allowed to be represented at the trial according to the prosecutor's summons, although Article 154 of the Criminal Procedure Code does not clearly explain the presence. The Criminal Procedure Code does not allow the implementation of justice in absentia (in absence) during ordinary investigations or brief investigations in terms of Article 154 paragraph (4) of the Criminal Procedure Code (Pangaribuan et al., 2017). The principle of the presence of the defendant has another name, namely ius singular. In addition, the principle of the presence of the defendant is related to the basis of the judge's direct and verbal investigation (Hamzah, 2001).

If during the implementation of the online trial, technical problems such as internet network disturbances are encountered, then in terms of the agenda for proving the examination of witnesses and/or experts as well as the statements of the defendant and other evidence, it cannot be carried out optimally or there may even be a misperception. In addition, if the legal counsel is not in a position with the defendant, and the legal adviser does not definitely see whether the witness and the defendant are in a position of pressure/lie. Hence, researchers are interested in conducting this study further about online trials in criminal cases in the Covid-19 pandemic era, especially analyzing the mechanism for applying procedural law and the evidentiary process. From the explanation of the problems above, the purpose of this study is to find out the online trial process during the covid-19 pandemic in Indonesia. 


\section{IMPLEMENTATION METHOD}

The method used in this research is using the normative law method, using the statute approach, which is to examine and analyze laws and regulations related to the topic of discussion. Besides that, case approach was utilized by analyzing cases that have been decided by the court, with this approach we can compare cases related to the narrative issues that will be discussed in this study (Bachtiar, 2019). This research use secondary data by using a literature study or literature review. Sugiyono (2015) stated that a study based on literature is a theoretical study through references related to the situation being studied, whether it is related to values, culture or norms.

Meanwhile, Zed (2004) argues that literature review is data collection carried out by collecting library sources, reading, and taking notes and processing the results from the sources that have been collected. In this study, the author uses a literature review method, which is an attempt to collect various information and data from various sources, such as journal articles, books, magazines, etc. as a source for the study being studied. The technique for analyzing the data that the author uses in this journal is to use the method of analyzing the content of information or data or what we usually know as content analysis. The analysis was carried out to obtain the acquisitions and results from the literature review in accordance with the things being studied. The process are carried out to obtain data is by selecting, comparing, combining, and sorting information, so that the acquisition of data related to the research topic is found.

\section{RESULTS AND DISCUSSION}

\subsection{Definition}

The trial etymologically is the meeting of someone who discusses something. The trial court is the implementation of the trial which is carried out in the court building and is open to the public. So that the defendant has the right to be able to present before the court by the public prosecutor based on the order of the next panel of judges to be examined, tried, and seek the right to a defense (Iswantoro, 2020).

According to the Supreme Court regulation article 1 paragraph 4 number 04 of 2020 concerning the implementation of the electronic court room, it is a court trial forum which is carried out virtually and attended by the relevant agencies.

Therefore, based on the description above, according to the author's opinion, the electronic trial is a process of resolving the problems of both parties by using electronic media as a trial room with a mechanism to examine, judge and decide where the trial is to reach a consensus.

\subsection{Court Process Through Online Media in Indonesia}

A rapid response to the Covid-19 pandemic is required in the trial mechanism. The government must set health protocols in the trial agenda that must be conducted online using electronic information systems where the parties are in their respective locations, with the legal umbrella issued by the Supreme Court No. 1 of 2019 regarding implementation instructions and technical instructions. As a result of the Supreme Court (MA) circular letter No. 1 of 2020, which deals with the present pandemic's regarding the implementation instructions and technical instructions (juklak juknis), the electronic version was further enhanced by Circular 3 of 2020.The regulation describes official activities within the judicial apparatus to transfer their official activities to their respective homes or better known as WFH (work from home). The WFH includes trial agendas, case investigations conducted virtually/online.

The decision to conduct a virtual/online trial based on the Attorney General's order number 5 of 2020 regarding policies for implementing duties and handling cases until the pandemic outbreak is under control (Razaq, 2020). Additionally, regarding the agreement between the Supreme Court, the Attorney General's Office of the Republic of Indonesia and the Ministry of Law and Human Rights regarding the conduct of the trial through online media, the agreement aims to achieve good, 


\section{POLICY, LAW, NOTARY AND REGULATORY ISSUES (POLRI) \\ VOLUME 1 ISSUE 1 (2022)}

optimal, effective, efficient and secure service in the conduct of the trial.

As a follow-up to the MoU conducted a virtual trial in accordance with the results of the decision of the Supreme Court's agreement to issue regulations on the administration of the trial on the basis of Supreme Court (MA) Regulation No.04 of 2020. The regulation regulates the mechanism of the implementation of criminal trials both criminal cases within the general court circle, the military, and jinayat online.

According to the author, with a definite source of law, it will make it easier to carry out tasks in accordance with its role and function as a judicial institution for that as a judicial institution that prioritizes aspects of service to the community that are more responsive and effective and efficient so that people get more attention and do not reduce community satisfaction in obtaining legal services. This matter was conveyed by Hasaziduhu that the aspect of legal certainty has a very influential influence on law enforcement of a statutory provision, although in fact this aspect must be balanced with the principles of justice and expediency (Moho, 2019).

Due to the online trial, the following factors must be considered or prepared for:

a. All participants must be visible on the monitor and audible on the microphone.

b. The clerk or substitute clerk must arrange the equipment for the implementation of the trial, starting with the trial facilities, the completeness of the elements of the trial and reports to the panel of judges.

c. During the trial process, the elements of the trial officers wear court uniforms in accordance with the respective provisions that apply in the procedural law.

d. The documents attached by the prosecution, legal counsel, and the defendant are in the form of softfiles in the Portable Document Format (PDF) format.

e. Document files are in the form of Portable Document Format (PDF that is attached, then download and confirm the softfile between the read and the downloaded).

Furthermore, for the administrative process of criminal case trials carried out through electronic media as regulated in PERMA No. 4 of 2020 concerning Administration and trial of criminal cases in court electronically;

\subsubsection{Court Preparation}

a. Before carrying out the trial, the clerk / substitute clerk prepares the ability of the trial participants and reports to the Judge and the Panel of Judge.

b. When the trial takes place electronically, the defendant and his legal advisor are in the same location as the legal advisor.

c. In the forum for conducting trials with online media, it is not intended for other people to enter other than the defendant, legal advisors and implementing officers related to the interests of the defendant in accordance with statutory regulations.

d. The trial forum at the location of the defendant who is conducting the trial must meet electronic equipment that can help run an open and transparent trial.

e. At the trial, the registrar/substitute clerk records the minutes of the trial from the beginning of the trial until the outcome of the trial decision is released.

According to the author's analysis, in preparation for the trial, it must be ensured, especially for the IT team, which is the main indicator of success in conducting online trials to support infrastructure facilities, so that technical errors does not occur during the trial, therefore the trial preparation mechanism must be fulfilled.

\subsubsection{Indictments and Objections}

a. The exception/objection document file is shared with the Judge/panel of Judge in the Portable Document Format (PDF) file format and shared with the prosecutor via the electronic mail link of the court who will conduct the trial before reading and verifying the downloaded trial document file. 
b. When the prosecutor feels an objection to the defendant / exception is sent to the judge / panel of judges, it is arranged in the manner as above.

c. Under certain conditions, the pronunciation of the court's decision can be read directly in the electronic trial.

According to the author's analysis, the indictment/objection document must be in accordance with the indictment because in the process of submitting and providing evidence as well as the preparation of the text/request letter, must not deviate from the applicable rules and must be based on an indictment as well as in carrying out exceptions and defenses as well as duplicates and legal remedies must not deviate and must always be based on an indictment.

\subsubsection{Witness and Expert Investigation}

a. In the process of investigation, witnesses/experts are carried out in the trial room provided by the court electronically.

b. In urgent conditions, the Judge/Panel of Judge may decide the location of the Witness and/or Expert's investigation as follows;

i. The place of the court officer element agency in its legal area;

ii. In the examination where the witness/expert is outside the jurisdiction of the court hearing the case, the witness/expert examination shall be conducted at the place where the witness/expert court is located.

iii. When the witness/expert is abroad, the witness/expert must obtain approval from the minister of foreign affairs.

iv. Other locations are decided by the Judge/Panel of Judge

According to the author's perspective, the examination process should be in a special location that is free from interference or intimidation from various parties, so that the examination is in accordance with operational procedures.

\subsubsection{Defendant's Examination}

In the examination of the defendant at the trial conducted electronically, the following shall be carried out:

a. The defendant who is in detention shall have his testimony heard from the place where he is being held, accompanied/unaccompanied by legal counsel;

b. The defendant who is in detention, but the place where the defendant is detained does not have facilities for an electronic trial, his testimony is heard from the prosecutor's office, or;

c. If the defendant is not detained, his testimony will be heard in court, prosecutor's office, or other place determined by the Judge/Panel of Judge through an stipulation.

However, if the defendant is not detained, the chairperson/head of the court where the defendant's testimony is heard provides trial facilities electronically and appoints 1 Judge and 1 Registrar/Substitute Registrar without using trial attributes to supervise the examination of the Defendant.

According to the author's analysis, in carrying out the examination, the defendant must obtain trial facilities according to operational procedures, and to get the opportunity to defend and provide information on what the defendant did to the defendant.

\subsubsection{Examination of Evidence}

In a trial conducted electronically, the evidence to be examined remains at the prosecutor's office. Then the prosecution shows the evidence to the Judge/Panel of Judge electronically.

a. If the evidence is in the form of a printed document, the Judge/Panel of Judge will match the scanned document in the case file with the original document that is shown by the prosecutor electronically.

b. If the evidence is not a printed document, then the evidence can be photographed/videoed and 


\section{POLICY, LAW, NOTARY AND REGULATORY ISSUES (POLRI) \\ VOLUME 1 ISSUE 1 (2022)}

then sent to the Court's e-mail address before being submitted as evidence.

c. If the Defendant submits mitigating evidence, both in the form of printed and non-printed documents, the evidence shall be treated in the same way as above.

d. The Judge/Panel of Judge matches the evidence sent with the original electronically.

According to the author's perspective, in conducting an examination of the evidence, the officer concerned must maintain the trust of the trial participants, so that impossible things happen such as sabotage, especially by conducting an electronic trial where the participants are not in the same room and also indications of intervention in favor of someone is very high and must anticipation.

\subsubsection{Claims, Defenses, Replies and Duplicates}

a. The criminal charges, defenses, replies and duplicates are read out before the court in accordance with the provisions of the Procedural Law.

b. When the trial is carried out virtually/electronically, the trial files such as the duplicate and duplicate defense claim files are shared via the court's electronic postal link prior to the submission of the court decision, then after being submitted, they are re-shared via the prosecutor/defendant's electronic postal link and/or or legal counsel.

According to the author opinion, at the stage of reading the demands or defense carried out by the defendant/legal counsel, it does not reduce the right of the defendant in submitting a defense, although there are some people who are not satisfied in submitting a defense during the process of conducting an electronic trial while receiving legal protection and no intervention occurs.

\subsubsection{Verdict and Notification of Judgment}

a. The decision is read out by the Judge/Panel of Judges in an open and public trial which is attended by the prosecutor and the defendant/legal counsel, unless otherwise stipulated by the law that applied

b. In certain situations, according to the decision of the Judge/Panel of Judge, the results of the trial can be submitted electronically.

c. When the defendant is not present at the time of delivering the results of the decision by the court to the defendant via electronic domicile or electronic mail.

d. If the defendant does not have an electronic domicile, then the delivery of the decision will be delivered through a decision letter to the address the defendant lives, attaching a copy to the village head or lurah. When the whereabouts of the defendant is unknown, the delivery of information related to the court results uses information boards and mass media and prints the court's website.

According to the author, in the process of notification of decisions other than those mentioned above, they must use a certain approach in notification of decisions, so that the treatment after notification of decisions is in accordance with what has been determined.

The trial implementation method as regulated in the explanation above in the online trial is indeed not regulated in the Criminal Procedure Code, but in accordance with the provisions of the procedural law article 64 of the Criminal Code it is stated that the defendant has the right to be tried in general court (Razaq, 2020) when the pandemic conditions are uncertain when it will end with the Supreme Court Regulation Number 4 of 2020 being an alternative in conducting online trials. As for the offline trial, it means that the trial is carried out as usual, that is, all trial participants and the process are in one room when the trial takes place without going through electronic media. Therefore, whenever it is possible to carry out an offline trial, it has been regulated in Article 2 Paragraph (1) of the Supreme Court Regulation as follows: "The trial is carried out in the Court's courtroom in the presence of the Prosecutor and the Defendant accompanied/unaccompanied by a Legal Counsel, unless otherwise determined based on the provisions of the legislation" 
If it is not possible to hold an offline trial and in uncertain conditions such as currently still in the Covid-19 pandemic situation, instead the trial can be held via online media/teleconference when starting the initial trial of the case or when the case trial is in progress. With regard to public access to online trials, it is explained in Article 18 of the Supreme Court Regulation "trials are conducted electronically, public spaces to gain access to administrative services or trials are carried out according to the rules of the law".

This trial using online media is indeed a transformation of the judicial system in Indonesia which is more modern and legal reform in Indonesia, especially during the Covid-19 pandemic. Where relevant policies are needed in order to solve stagnant problems in cases due to the spread of Covid-19 if the trial is only carried out offline. Hence, to fulfill the legal rights of the defendant, it is still fulfilled optimally. For example, the principle of fast justice (not long-winded), simple (because it is carried out through electronic media or teleconference), and low costs can really be felt for justice seekers.

This online trial is a form of ultramodern law that emphasizes the basic principles of law, namely the community's need for the law itself, legal certainty, expediency, and justice (Lumbanraja, 2020). Therefore, the implementation of case trials through online media with an uncertain pandemic situation as it is today, with this solution is the right decision and must be maximized by the Supreme Court, if legal institutions do not carry out legal reforms in Indonesia, new problems will arise and a decline will occur in legal services for people who are still dealing with legal problems (Iswantoro, 2020).

By the Supreme Court regulation number 4 of 2020, one of the efforts to be responsible for the community is to obtain legal services that are easily accessible to the public to ensure and create legal certainty, dignified justice for defendants, prosecutors, advocates, and judges and also the costs incurred are simple, effective and efficient in current conditions, so that the community is not hampered in legal services.

However, the application of online trials in criminal cases as part of legal reform must continue to be carried out and developed as a response to the evolving socio-cultural environment without abandoning the principles of other criminal justice systems, such as defendants, witnesses and/or experts being treated according to the rules according the eyes of the law (no discrimination and no intervention). In addition, as stated by Ihwan and Nugraheni (2021), the existence of an online court supervision system is also an important note that can be realized in the form of legal provisions and other supervisory systems.

\section{CONCLUSION}

With the current state of the Covid-19 pandemic, which alters the pattern of people's lives and forces them to limit their activities, it is essential that a quick response be implemented to address the situation. It is necessary to transform the judicial environment to provide legal services to the community, such as the mechanism of applying event law in the implementation of the trial with online media / teleconference, after which the Supreme Court Regulation No. 4 of 2020 with the regulation of the trial organizers can choose the form of trial in criminal cases, namely online and offline, for offline trials are carried out as in general, namely in one room directly, while for online trials are carried out as in general, namely via online media / teleconference, after which the Supreme In Indonesia, the trial is being held as part of a reform of the country's modern justice system.

\section{REFERENCES}

Akbar, A., \& Sabri, F. (2021). Kekuatan Pembuktian Dalam Persidangan Perkara Pidana Secara Elektronik. Soumatera Law Review, 4(1), 120-134.

Bachtiar, B. (2019). Metode Penelitian Hukum.

Hamidah, A. (n.d.). Legalitas Persidangan Online Dalam Sistem Peradilan Pidana Indonesia. Jurnal 
Hukum Fakultas Hukum Univeritas Bung Hatta. Retrieved August 14, 2021, from https://hukum.bunghatta.ac.id

Hamzah, A. (2001). Hukum acara pidana Indonesia.

Hanafi, H., Fitri, M. S., \& Ansori, F. (2021). Eksistensi Persidangan Online Ditengah Pandemi Covid19 Dalam Perkara Pidana Di Indonesia. Al-Adl: Jurnal Hukum, 13(2), 320-341.

Ihwan, M., \& Nugraheni, P. D. (2021). Urgensi Sistem Pengawasan dalam Pelaksanaan Persidangan Secara Online. Jurnal Al Azhar Indonesia Seri Ilmu Sosial, 2(2), 93-98.

Iswantoro, W. (2020). Persidangan Pidana Secara Online, Respon Cepat Ma Hadapi Pandemi Covid19. Jurnal Hukum Dan Bisnis (Selisik), 6(1), 56-63.

Lumbanraja, A. D. (2020). Perkembangan Regulasi dan Pelaksanaan Persidangan Online di Indonesia dan Amerika Serikat Selama Pandemi Covid-19. Crepido, 2(1), 46-58.

Mandasari, Z. (2013). Kedudukan Memorandum Of Understanding dan Surat Keputusan Bersama Ditinjau dari Teori Perundang-undangan. Jurnal Hukum IUS QUIA IUSTUM, 20(2), 278-299.

Matondang, P. (n.d.). Gagasan Penataan Kewenangan Penyelidikan Dan Penyidikan Dalam Tindak Pidana KorupsI. Jurnal Ilmu Hukum, 7(1), 35-45.

Moho, H. (2019). Penegakan Hukum di Indonesia Menurut Aspek Kepastian Hukum, Keadilan dan Kemanfaatan. Warta Dharmawangsa, 13(1).

Pangaribuan, A. M. A., Mufti, A., \& Zikry, I. (2017). Pengantar Hukum Acara Pidana Di Indonesia, Jakarta: PT. Raja Grafindo.

Razaq, N. A. (2020). LEGALITAS PERSIDANGAN DARING DI MASA PANDEMI COVID-19 DALAM PESPEKTIF HUKUM PIDANA. Jurnal Inovasi Penelitian, 1(6), 1227-1230.

Sugiyono, M. (2015). penelitian \& pengembangan (Research and Development/R\&D). Bandung: Penerbit Alfabeta.

Yahya, A. N. (2020). Menyoal Payung Hukum Persidangan Online. https://nasional.kompas.com/read/2020/07/09/07160431

Zed, M. (2004). Metode peneletian kepustakaan. Yayasan Obor Indonesia. 